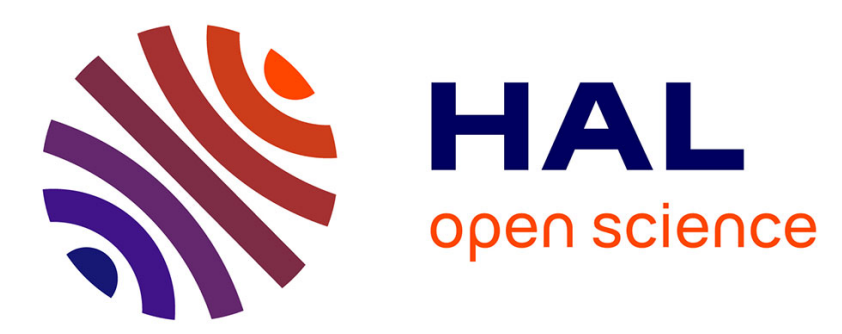

\title{
Extraction of oil from jatropha seeds using a twin-screw extruder: Feasibility study
}

Philippe Evon, Ika Amalia Kartika, Muriel Cerny, Luc Rigal

\section{To cite this version:}

Philippe Evon, Ika Amalia Kartika, Muriel Cerny, Luc Rigal. Extraction of oil from jatropha seeds using a twin-screw extruder: Feasibility study. Industrial Crops and Products, 2013, vol. 47, pp. 33-42. 10.1016/j.indcrop.2013.02.034 . hal-00815299

\section{HAL Id: hal-00815299 \\ https://hal.science/hal-00815299}

Submitted on 18 Apr 2013

HAL is a multi-disciplinary open access archive for the deposit and dissemination of scientific research documents, whether they are published or not. The documents may come from teaching and research institutions in France or abroad, or from public or private research centers.
L'archive ouverte pluridisciplinaire HAL, est destinée au dépôt et à la diffusion de documents scientifiques de niveau recherche, publiés ou non, émanant des établissements d'enseignement et de recherche français ou étrangers, des laboratoires publics ou privés. 


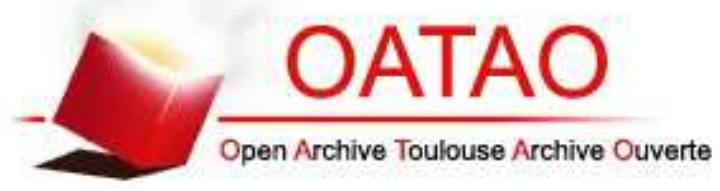

\section{Open Archive Toulouse Archive Ouverte (OATAO)}

OATAO is an open access repository that collects the work of Toulouse researchers and makes it freely available over the web where possible.

This is an author-deposited version published in: http://oatao.univ-toulouse.fr/ Eprints ID: 8609

To link to this article: DOI: $10.1016 / \mathrm{j}$. indcrop.2013.02.034

URL: http://dx.doi.org/10.1016/j.indcrop.2013.02.034

To cite this version: Evon, Philippe and Kartika, Ika Amalia and Cerny, Muriel and Rigal, Luc Extraction of oil from jatropha seeds using a twinscrew extruder: Feasibility study. (2013) Industrial Crops and Products, vol. 47 . pp. 33-42. ISSN 0926-6690

Any correspondence concerning this service should be sent to the repository administrator: staff-oatao@ listes-diff.inp-toulouse.fr 


\title{
Extraction of oil from jatropha seeds using a twin-screw extruder: Feasibility study
}

\author{
Ph. Evon a,b,*, I. Amalia Kartikac ${ }^{c}$ M. Cerny ${ }^{a, b}$, L. Rigal $^{\mathrm{a}, \mathrm{b}}$ \\ a Université de Toulouse, INP, Laboratoire de Chimie Agro-industrielle, ENSIACET, 4 Allée Emile Monso, BP 44362, 31030 Toulouse Cedex 4, France \\ ${ }^{\mathrm{b}}$ INRA, Laboratoire de Chimie Agro-industrielle, 31030 Toulouse Cedex 4, France \\ ${ }^{c}$ Department of Agroindustrial Technology, FATETA-IPB, Darmaga Campus, P.O. Box 220, Bogor 16002, Indonesia
}

Keywords:

Twin-screw extruder

Jatropha

Oil extraction

Oil quality

\begin{abstract}
A B S T R A C T
The objective of this study was to evaluate the feasibility of mechanical pressing to extract oil from jatropha seeds using a twin-screw extruder. Experiments were conducted using a co-rotating (Clextral BC 21, France) twin-screw extruder. The influence of operating conditions on oil yield, specific mechanical energy and oil quality was examined. Operating conditions included screw configuration, pressing temperature and screw rotation speed.

Generally, it was the screw configuration, or profile, that most affected oil extraction efficiency. The best oil yields, a minimum 57.5\%, were obtained with a trituration zone composed of 10 monolobe and 10 bilobe paddles, and a pressing zone composed of $50 \mathrm{~mm}$ long, reverse pitch screws with a $-33 \mathrm{~mm}$ pitch. In addition, oil extraction yield increased with decreasing temperature and screw rotation speed. Highest oil extraction yield (70.6\%) with good press cake quality (residual oil content lower than $8 \%$ ) was obtained under operating conditions of $153 \mathrm{rpm}$ screw rotation speed, $5.16 \mathrm{~kg} / \mathrm{h}$ inlet flow rate of jatropha seeds, and $80^{\circ} \mathrm{C}$ pressing temperature. The corresponding expressed oil was inexpensive to produce ( $71 \mathrm{Wh} / \mathrm{kg}$ seed processed or $314 \mathrm{Wh} / \mathrm{kg}$ expressed oil for specific mechanical energy) compared with another continuous technique, i.e. the single expeller press, commonly used for mechanical extraction of jatropha oil. Its quality was also satisfactory for biodiesel production. The acid value, the density and the kinematic viscosity were $5.4 \mathrm{mg}$ of $\mathrm{KOH} / \mathrm{g}$ of oil, $915 \mathrm{~kg} / \mathrm{m}^{3}$ and $36.7 \times 10^{-6} \mathrm{~m}^{2} / \mathrm{s}$, respectively.
\end{abstract}

\section{Introduction}

Jatropha curcas is a drought-resistant shrub or tree belonging to the family Euphorbiaceae, which is cultivated in Central and South America, South-East Asia, India and Africa (Gubiz et al., 1999). It is a plant with many attributes, multiple uses and considerable potential (Openshaw, 2000; Achten et al., 2008; Kumar and Sharma, 2008). In Indonesia, the land area under jatropha is increasing because this plant can be used to reclaim land, prevent and/or control erosion, plus it provides a new agricultural development mode with no competition between food and non-food uses. The seed is the part of the jatropha plant with the highest potential for utilization. It contains between 40 and $60 \%$ oil, and between 20 and $30 \%$ proteins. The jatropha seed is generally toxic to humans and animals, with phorbol ester and curcin identified as the main toxic agents (Gubiz et al., 1999; Haas and Mittelbach, 2000).

\footnotetext{
* Corresponding author at: Université de Toulouse, INP, Laboratoire de Chimie Agro-industrielle, ENSIACET, 4 Allée Emile Monso, BP 44362, 31030 Toulouse Cedex 4, France. Tel.: +33 5624460 80; fax: +33 562446082 .

E-mail address: Philippe.Evon@ensiacet.fr (Ph. Evon).
}

J. curcas oil is regarded as a potential alternative to diesel fuel, and vegetable oils have numerous advantages in this respect because they are non toxic, and safe to store and handle because of their high flash points. The fact that jatropha oil cannot be used for nutritional purposes without detoxification, makes its use as an energy source for fuel production very attractive. The use of biodiesel from jatropha oil is a promising alternative to fossil fuel because it is renewable, and environmentally friendly, and can also be produced locally.

Conventional industrial technology for the synthesis of biodiesel from vegetable oils, involves isolation of the oil from the seed, refining, and then transesterification. Industrial oil extraction from oilseeds, is usually carried out by mechanical pressing with a hydraulic or single expeller press, followed by solvent extraction with n-hexane. The hydraulic press is highly effective for industrial extraction of oil from oilseeds by mechanical pressing, but it is a discontinuous process. However, the last twenty years has seen much, focused research concerning continuous oil extraction using extrusion technology (Isobe et al., 1992; Crowe et al., 2001; Wang and Johnson, 2001; Singh et al., 2002; Zheng et al., 2003). This process in a single-screw press, is widely used for oilseeds, with a singlescrew of variable pitch and channel depth, slowly rotating in a cage 
type barrel (Isobe et al., 1992). However, transport of material in this type of press, depends mainly on friction between the material and the barrel's inner surface and screw surface during screw rotation. Thus a solid, core component is often necessary to produce this friction, causing overheating, high energy consumption, and oil deterioration. Furthermore, single-screw presses provide insufficient crushing and mixing if they are not equipped with breaker bars, or other special equipment.

A twin-screw oil press can be expected to solve these problems because of the higher transportation force, similar to a gear pump, and better mixing and crushing at the twin-screw interface, improving mechanical lysis of the cells. In addition, energy consumption of the twin-screw press is more efficient (Isobe et al., 1992; Bouvier and Guyomard, 1997). Thus increasingly, twin-screw extrusion technology has been used successfully to undertake mechanical pressing of various oilseeds (Isobe et al., 1992; Guyomard, 1994; Bouvier and Guyomard, 1997; LacazeDufaure et al., 1999; Amalia Kartika et al., 2005, 2006; Evon et al., 2007, 2009; Faye, 2010; Sriti et al., 2012).

The advantages of twin-screw extruders stem from their capacity to carry out various functions and processes. According to Dziezak (1989), these include (i) an ability to provide better process control and versatility, especially in pumping efficiency, control of residence time distribution, and uniformity of processing, (ii) an ability to process specialty formulations, which the single-screw extruder cannot handle and (iii) machine setup flexibility, allowing self-cleaning mechanisms and rapid changeover of screw configurations without disassembling the extruder.

Co-penetrating and co-rotating twin-screw extruders are the most common (Dziezak, 1989), and a very wide choice of screw elements is available. The latter affect different functions such as conveying, heating, cooling, shearing, crushing, mixing, chemical reactions, liquid/solid extraction, liquid/solid separation, and drying (Rigal, 1996). The screw profile defines the arrangement of screw elements with different characteristics (pitch, stagger angle, and length) in different positions and with different spacing. It is the main factor influencing performance (product transformation, residence time distribution, and mechanical energy input) during extrusion processing (Gogoi et al., 1996; Choudhury et al., 1998; Gautam and Choudhury, 1999a,b).

The forward pitch screws mainly ensure conveying action. The monolobe paddles exert radial compression and shearing action on the matter but have limited mixing ability. The bilobe paddles, in combination with forward pitch screws, exert significant mixing, shearing, conveying, and axial compression actions on the matter. The bilobe paddles favor the intimate mixing required for the liquid/solid extraction of soluble components in the cell structure. Finally, the reverse pitch screws produce intensive shearing and considerable mixing of the matter, and exert a strong axial compression in combination with the forward pitch screws (Rigal, 1996). The reverse pitch screws are frequently used to put pressure on the matter, which is essential for the subsequent separation of liquid and solid phases by filtration.

When oleic sunflower oil is expressed using a twin-screw extruder, a longer reverse pitch screw improves oil yield, which can attain $80 \%$ under optimized operating conditions (Lacaze-Dufaure et al., 1999). When two reverse pitch screws are used, oil yield increases as the distance between them increases, and also with a decrease in the screw pitch (Amalia Kartika et al., 2005). The optimum oil yield obtained with such a screw configuration is close to $70 \%$ but the introduction of a second filtration zone improves this to 85\% (Amalia Kartika et al., 2005). The corresponding press cake contains less than $13 \%$ residual oil and the quality of the oil produced is similar to that obtained using traditional industrial extraction.

For jatropha seeds, no previous study has dealt with the use of twin-screw extrusion technology for oil extraction by mechanical pressing. However, the use of such a technology appears promising, even if the equipment and maintenance costs must be carefully considered. For the moment, mechanical oil extraction from jatropha seeds is generally carried out using a hydraulic press (Tambunan et al., 2012) or a single expeller press (Karaj and Müller, 2011; Pradhan et al., 2011; Ofori-Boateng et al., 2012). Similarly, oil extraction efficiency is quite promising using a Komet D85-1G (Germany) mechanical screw press (Karaj and Müller, 2011). Yield in this case attains $89.3 \%(\mathrm{~m} / \mathrm{m})$ under optimum operating conditions ( $16 \mathrm{~mm}$ for single screw pitch, $1.5 \mathrm{~mm}$ mesh size for press cylinder, $8 \mathrm{~mm}$ for nozzle restrictor size, $220 \mathrm{rpm}$ for screw rotation speed, and $4.0 \mathrm{~kg} / \mathrm{h}$ for throughput of jatropha seeds), leading to a specific energy input of $462 \mathrm{Wh} / \mathrm{kg}$ seed processed, or about $1.6 \mathrm{~kW} \mathrm{h/kg} \mathrm{expressed} \mathrm{oil.} \mathrm{Residual} \mathrm{oil} \mathrm{content}$ in the corresponding press cake is only $5.6 \%$.

This study aims to show that a co-rotating twin-screw extruder can be used for the extraction of oil from jatropha seeds by mechanical pressing. It proposes to evaluate the effects of screw configuration, pressing temperature and screw rotation speed on oil extraction efficiency. The extraction performance characterization is assessed by determining extraction yield, mechanical energy input and oil quality.

\section{Materials and methods}

\subsection{Materials}

All trials were carried out using a single batch of jatropha seeds (IP2 Lampung variety) supplied by the Indonesian Spices and Industrial Crops Research Institute (Sukabumi, Indonesia). The harvested fruits were first dried at ambient temperature. The capsules were then removed manually to obtain the seeds, which were $17-18 \mathrm{~mm}$ long ( $x$-axis), $10-11 \mathrm{~mm}$ wide ( $y$-axis) and $8-9 \mathrm{~mm}$ thick ( $z$-axis). And in order to facilitate their introduction into the twin-screw extruder, they were crushed before the study using a universal cutting mill (Fritsch Pulverisette 19, Germany) with no sieve insert fitted. After milling, most of the kernels were separated from the shells in the ground material. The solid particles from the kernels were $10-13 \mathrm{~mm}$ long ( $x$-axis), $6-8 \mathrm{~mm}$ wide ( $y$-axis) and $3-4 \mathrm{~mm}$ thick ( $z$-axis). The moisture content was $5.49 \pm 0.10 \%$ (French standard NF V 03-903). All solvents and chemicals were analytical grade and were obtained from Merck (Germany), Macherey-Nagel (Germany), Sigma-Aldrich (USA) and Prolabo (France).

\subsection{Twin-screw extruder}

Experiments were conducted with a Clextral BC 21 (France) co-rotating and co-penetrating twin-screw extruder. This consists of two identical, co-rotating and intermeshing screws. The two shafts turn in the same direction and the various paired (twin) screw setups, opposite each other in the different modules, thus co-rotate and intermesh (co-penetrate). It had seven, $100 \mathrm{~mm}$ long modular barrels, and different twin-screws made up of segmental screw elements, 25 and $50 \mathrm{~mm}$ in length (Fig. 1). Modules 2, 3, 4, 5 and 7 were temperature controlled (electrically heated, and water cooled). Crushed jatropha seeds were fed into the extruder inlet port using a volumetric screw feeder (K-Tron Soder KCL-KT20, Switzerland). They entered a sequence of three operations: conveying (forward pitch screws) in module 1, trituration (a succession of 10 monolobe paddles and one or two series of 10 bilobe paddles) in modules 2-4 or 5 and pressing (reverse pitch screws) in module 7. A filter section consisting of four hemispherical dishes with $500 \mu \mathrm{m}$ diameter perforations was positioned on module 6 to enable the filtrate (oil containing the 'foot', i.e. the solid particles forced through the filter) to be collected separately from the press cake. Screw 


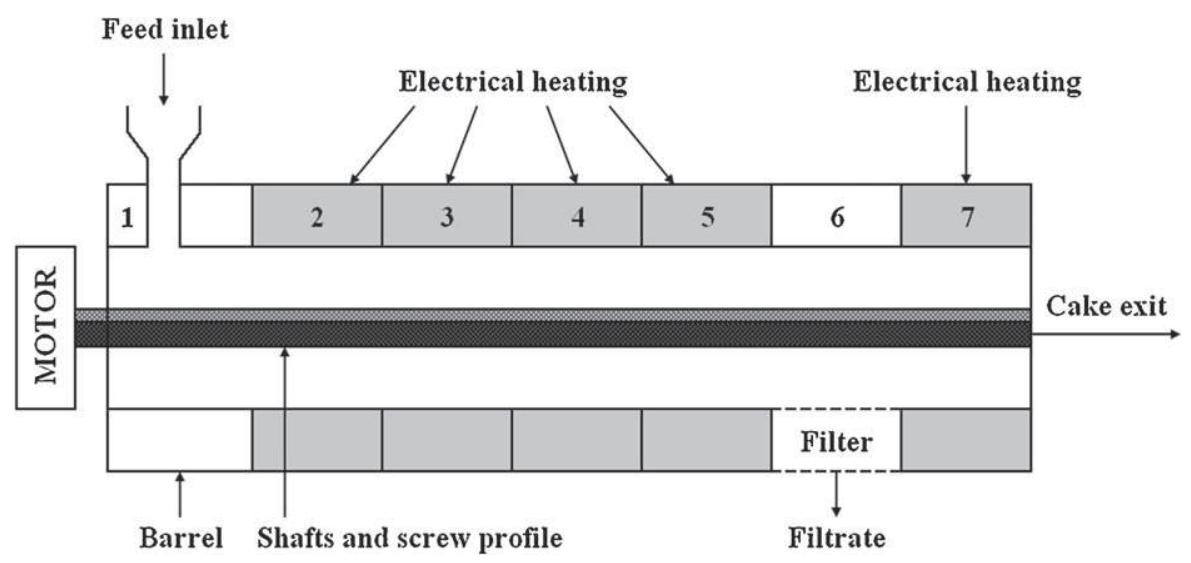

Fig. 1. Schematic modular barrel of the Clextral BC 21 twin-screw extruder used for extraction of oil from jatropha seeds.

rotation speed $\left(S_{S}\right)$, seed feed rate $\left(Q_{S}\right)$, and barrel temperature $\left(\theta_{c}\right)$ were monitored from a control panel.

The four screw profiles (1-4) tested in this study were based on those used in Amalia Kartika et al. $(2005,2006)$ for sunflower oil extraction. The differences between them concerned their trituration zones, situated in modules $2-4$ or 5 , and their pressing zones, situated in module 7 . The trituration zone was composed of a succession of 10 monolobe paddles and two series of 10 bilobe paddles for profiles 1 and 2. But, it was shorter for profiles 3 and 4 with 10 monolobe paddles and only one series of 10 bilobe paddles. For the pressing zone, the reverse pitch screws used in profiles $1-3$ were $25 \mathrm{~mm}$ long, with a pitch of $-16 \mathrm{~mm}$. They were positioned immediately after the filtration module for profiles 1 and 3, and $25 \mathrm{~mm}$ from the end of module 6 for profile 2 . The reverse pitch screws used in profile 4 were longer ( $50 \mathrm{~mm}$ instead of $25 \mathrm{~mm}$ ), their pitch was greater $(-33 \mathrm{~mm}$ instead of $-16 \mathrm{~mm})$, and they were positioned immediately after the filtration module.

\subsection{Experimental}

Thirteen experiments were conducted for the expression of oil from jatropha seeds in the twin-screw extruder (Table 1). Different operating conditions were tested including screw profile, screw rotation speed and temperature in the pressing zone. The feed flow of jatropha seeds was around $5 \mathrm{~kg} / \mathrm{h}$ for all the experiments, meaning that the device's filling coefficient depended directly on the screw rotation speed. For each screw profile tested, this speed had to remain above a limit value to avoid the twin-screw extruder becoming clogged: 55-60 rpm for profiles 1 and 2, around $65 \mathrm{rpm}$ for profile 3 , and around $140 \mathrm{rpm}$ for profile 4 , respectively.

For each experiment, the extruder was left to function for $30 \mathrm{~min}$ before any sampling, to ensure stabilization of the operating conditions (seed feed flow, temperature, and motor torque). After this, the filtrate and the press cake were immediately collected for a period long enough ( $30 \mathrm{~min}$ ), to minimize any variation in the outlet flow rates. Sample collection, timed using a stopwatch, was carried out once for each trial, meaning that the thirteen experiments were not replicated. The filtrate and the press cake were weighed, and the filtrate was then centrifuged $\left(8000 \times \mathrm{g}, 15 \mathrm{~min}, 20^{\circ} \mathrm{C}\right)$ to eliminate the foot.

The oil yields were calculated from the following formulae:

$R_{L}=\frac{Q_{F} \times T_{L}}{Q_{S} \times L_{S}} \times 100$,

where $R_{L}$ is the oil yield relative to the total oil that the seed contains (\%), $Q_{S}$ the inlet flow rate of jatropha seeds $(\mathrm{kg} / \mathrm{h}), Q_{F}$ the flow rate of the filtrate $(\mathrm{kg} / \mathrm{h}), T_{L}$ the mass content of the expressed oil in the filtrate (\%), and $L_{S}$ the total oil content in the jatropha seeds (\%).

$R_{C}=\frac{\left(Q_{S} \times L_{S}\right)-\left(Q_{C} \times L_{C}\right)}{Q_{S} \times L_{S}} \times 100$,

where $R_{C}$ is the oil yield based on the residual oil content of the press cake (\%), $Q_{C}$ the flow rate of the press cake $(\mathrm{kg} / \mathrm{h})$, and $L_{C}$ the oil content in the press cake (\%).

Although $R_{L}$ and $R_{C}$ are expressed in terms of the oil in the seed, $R_{C}$ is always higher than $R_{L}$ because it includes all the oil in the filtrate (expressed oil plus oil in the foot).

The energy consumed by the motor was determined from the following formulae:

$P=P_{M} \times \frac{S_{S}}{S_{\max }} \times \frac{T}{T_{\max }} \times \cos \varphi$,

where $P$ is the electrical power supplied by the motor (W), $P_{M}$ the motor's power rating $\left(P_{M}=8300 \mathrm{~W}\right), T$ and $T_{\max }$ the test torque and maximum torque (100\%) of the extruder motor (\%), $\cos \varphi$ its theoretical yield ( $\cos \varphi=0.90)$, and $S_{S}$ and $S_{\max }$ the test speed and maximum speed $(682 \mathrm{rpm})$ of the rotating screws (rpm), respectively.

$S M E=\frac{P}{Q_{S}}$,

where SME is the specific mechanical energy consumed by the motor per unit weight of jatropha seeds $(\mathrm{Wh} / \mathrm{kg})$.

$S M E^{\prime}=\frac{P}{Q_{F} \times T_{L}}$,

where $S M E^{\prime}$ is the specific mechanical energy consumed by the motor per unit weight of expressed oil ( $\mathrm{Wh} / \mathrm{kg})$.

For trial 13 , the extruder was stopped immediately after sample collection, and opened in order to observe the matter inside. This was collected in ten successive zones along the profile (profile 4). Each sample collected was weighed, and dried overnight in a ventilated oven $\left(105^{\circ} \mathrm{C}\right)$ to determine its moisture content. Then, the samples collected in zones $1,4,6$, and 10 were observed with a Nachet France Z $45 \mathrm{P}$ (France $) \times 15$ binocular magnifier, and five different photographs were taken of each sample, and analyzed using the Archimed 4.0 (France) software. Particle size distribution was determined by manually measuring the diameter of all the particles on the five photographs, using the ImageJ (USA) software.

\subsection{Analytical methods}

The various constituents were determined according to the following French standards: moisture content NF V 03-903; mineral 


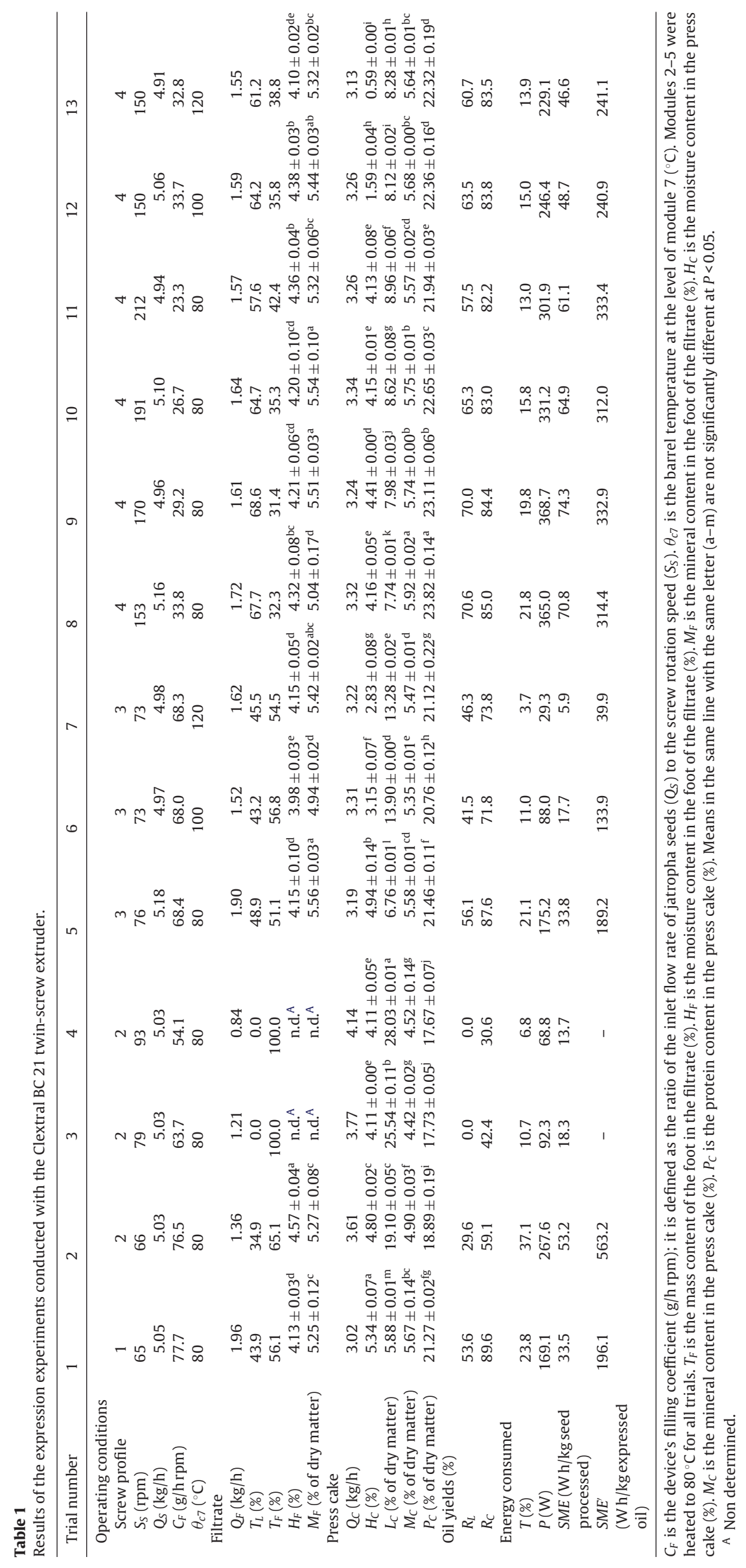


contents NF V 03-322; oil contents NF V 03-908; protein contents NF V 18-100. For the oil content determination, jatropha oil was extracted from the initial material (seeds or press cakes) using the Soxhlet extraction apparatus and n-hexane as extracting solvent. Oil extraction was carried out in two successive steps each of $5 \mathrm{~h}$ duration, in order to avoid underestimating the oil content. Between these two steps, the material was reground using a Foss Cyclotec 1093 (Denmark) mill fitted with a $300 \mu \mathrm{m}$ screen. All determinations were carried out in duplicate.

\subsection{Oil quality analysis}

The following quality parameters were calculated for the expressed oils; (i) the acid value and the acidity (based on oleic acid), expressed in $\mathrm{mg}$ of $\mathrm{KOH} / \mathrm{g}$ of oil and in \%, respectively (French standard NF T 60-204), which are an indication of the oil's free fatty acid content, (ii) the iodine value, expressed as the number of centigrams of iodine absorbed per gram of oil (French standard NF T 60-203), which is a measure of the degree of unsaturation of the oil (the higher the iodine value, the greater the degree of unsaturation), and (iii) the phosphorus content, expressed in $\mathrm{mg}$ of phosphorus per kg of oil (French standard NF T 60-227), which determines phosphorus or the equivalent phosphatide content by ashing the oil in the presence of magnesium oxide, followed by the spectrophotometric measurement of phosphorus as a yellow phosphovanadomolybdic complex. Total phospholipid content was determined by multiplying the phosphorus content by 26 , as suggested in the French standard NF T 60-227 concerning vegetable oils in general. All determinations were carried out in duplicate.

In addition, the density of expressed oils, in $\mathrm{kg} / \mathrm{m}^{3}$, was determined at $25^{\circ} \mathrm{C}$ using a method described by the Association of Official Analytical Chemists (AOAC, 2006). The dynamic viscosity of expressed oils, in mPa s, was measured at $40^{\circ} \mathrm{C}$ using a Carri-med CSL 100 (USA) controlled stress rheometer equipped with a coneplate geometry ( $40 \mathrm{~mm}$ diameter, $3^{\circ} 59$ angle), and the shear stress applied was $30 \mathrm{~N} / \mathrm{m}^{2}$. The kinematic viscosity at $40^{\circ} \mathrm{C}$, expressed in $10^{-6} \mathrm{~m}^{2} / \mathrm{s}$, was calculated as the ratio of the dynamic viscosity to the density of the oil. All determinations were carried out in duplicate.

\subsection{Fatty acid composition of Soxhlet extracted oil, and expressed oils from jatropha seeds}

The fatty acid composition of Soxhlet extracted oil (i.e. the oil extracted from jatropha seeds using the Soxhlet extraction apparatus and n-hexane as extracting solvent), and expressed oils, was determined by gas chromatography (GC). The sample analyzed was diluted in tert-butyl methyl ether (TBME) with a concentration of around $20 \mathrm{mg} / \mathrm{mL}$. A $100 \mu \mathrm{L}$ aliquot of the prepared sample was then converted to methyl esters according to the French standard NF ISO 5508 using $50 \mu \mathrm{L}$ of $0.5 \mathrm{~mol} / \mathrm{L}$ trimethylsulfonium hydroxide (TMSH) in methanol.

The fatty acid methyl esters were then analyzed by GC using a Varian 3800 (USA) gas chromatograph, equipped with a flame ionization detector. The carrier gas was helium with a flow rate of $1.2 \mathrm{~mL} / \mathrm{min}$. Methyl esters were separated in a CP Select CB (Varian, USA) fused silica capillary column ( $50 \mathrm{~m}, 0.25 \mathrm{~mm}$ i.d., $0.25 \mu \mathrm{m}$ film thickness). The initial oven temperature was held at $185^{\circ} \mathrm{C}$ for $40 \mathrm{~min}$, increased at a rate of $15^{\circ} \mathrm{C} / \mathrm{min}$ to $250^{\circ} \mathrm{C}$ and then held there for $10 \mathrm{~min}$. The injector and detector temperatures were $250^{\circ} \mathrm{C}$. All determinations were carried out in duplicate.

\subsection{Statistical analyses}

All determinations were conducted in duplicate and data are expressed as means \pm SD. The means were compared by using the single-factor analysis of variance (ANOVA) followed by Duncan's multiple range tests. The differences between individual means were fixed to be significant at $P<0.05$. All analyses were performed by using the SAS data analysis software.

\section{Results and discussion}

\subsection{Chemical composition of the jatropha seeds}

The oil content of the jatropha seeds used in this study was $33.73 \pm 0.34 \%$ of the dry matter, and this agrees with the $22-48 \%$ results reported by some researchers (Achten et al., 2008; Becker and Makkar, 2008). Mineral and protein contents were $4.81 \pm 0.08 \%$ of the dry matter and $15.64 \pm 0.19 \%$ of the dry matter, respectively. The fatty acid composition of the oil extracted from the jatropha seeds using the Soxhlet extraction apparatus and n-hexane as extracting solvent was myristic $(0.12 \pm 0.01 \%)$, palmitic $(14.12 \pm 0.17 \%)$, palmitoleic $(0.81 \pm 0.02 \%)$, stearic $(7.14 \pm 0.29 \%)$, oleic $(43.49 \pm 0.79 \%)$, linoleic $(32.90 \pm 0.80 \%)$, linolenic $(0.17 \pm 0.01 \%)$, arachidic $(0.22 \pm 0.01 \%)$, gadoleic $(0.33 \pm 0.02 \%)$, and behenic $(0.71 \pm 0.02 \%)$. Thus, the oil expressed in this study was rich in oleic and linoleic fatty acids, like other jatropha oils described in the literature (Foidl et al., 1996; Gubiz et al., 1999; Haas and Mittelbach, 2000; Openshaw, 2000; Achten et al., 2008; Becker and Makkar, 2008; Kumar and Sharma, 2008 ), and contained $1.8 \pm 0.0 \%$ of free fatty acids.

\subsection{Influence of the operating conditions on oil extraction efficiency}

As observed in previous studies dealing with the extraction of sunflower oil (Lacaze-Dufaure et al., 1999; Amalia Kartika et al., 2005, 2006; Evon et al., 2007, 2009), the extruder was effective because of its capacity to crush the jatropha seeds whilst pressing. The trituration zone (monolobe and bilobe paddles) reduced the size of the solid particles significantly, and this mechanical action led to the release of part of the oil, and the compressing action by the reverse pitch screws was essential for liquid/solid separation. Positioned at the beginning of module 7, the CF2C reverse pitch screws pushed part of the mixture upstream against the general movement in the extruder, and this counter pressure ensured the efficiency of the liquid/solid separation above the metal filter.

For all the experiments, filtrate samples and press cake samples were always collected separately. The oil content in the press cake was lower than in the jatropha seeds and it varied from 28.0 to $5.9 \%$ of the dry matter (Table 1 ) depending on the operating conditions used. This led to an oil yield $\left(R_{C}\right)$, based on the residual oil content of the press cake, of between 30.6 and 89.6\% (Table 1). Logically, the higher the oil yield $\left(R_{C}\right)$ the lower the oil content in the press cake, and this relation was indeed linear. The protein content in the press cake was higher than in the actual jatropha seeds due to the oil expression, and it varied from 17.7 to $23.8 \%$ of the dry matter (Table 1). In addition, for all the screw profiles tested, the lower the oil content in the press cake, the higher its protein content. The oil yield $\left(R_{L}\right)$, defined as the ratio of the expressed oil to the total oil that the seed contained, varied from 0.0 to $70.6 \%$ (Table 1 ). It was always lower than the oil yield $\left(R_{C}\right)$ due to the oil contained in the filtrate foot (Fig. 2), and the difference between these two oil yields tended to increase with increasing filtrate foot content.

Moreover, the mass content of the foot in the filtrate was at least $31 \%$, which seems high compared to values generally obtained with single-screw presses (usually less than $5 \%$ ). The use of a filter section with smaller perforations (less than $500 \mu \mathrm{m}$ in diameter), would probably reduce the amount of solid particles forced 


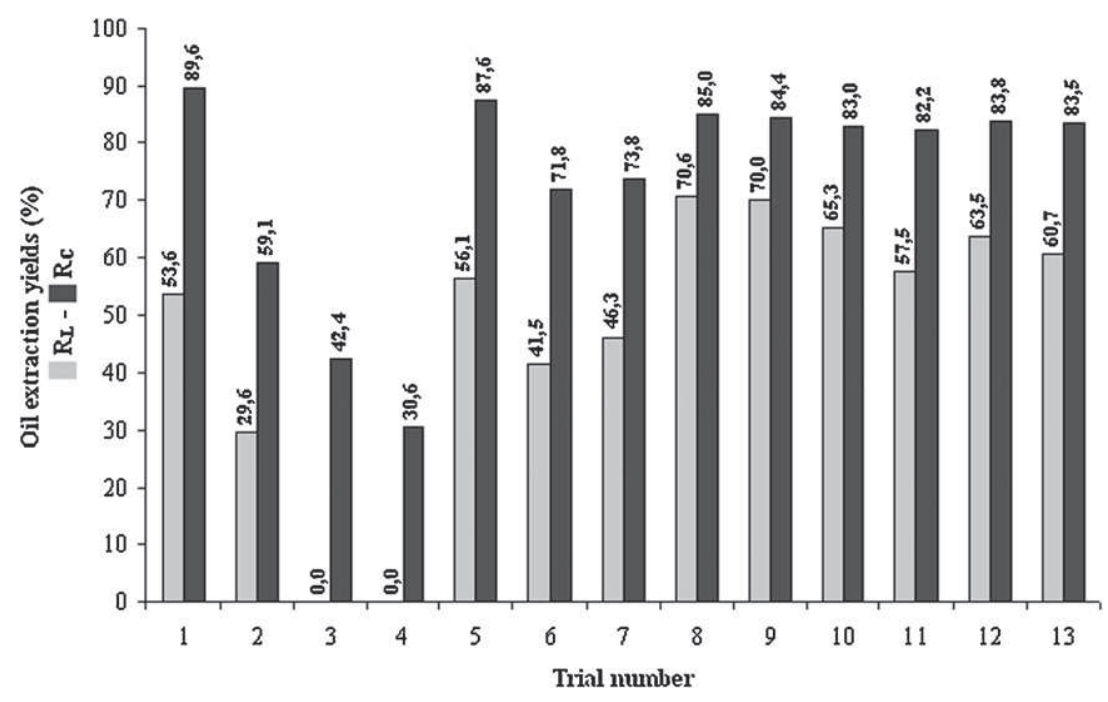

Fig. 2. Variation in oil extraction yields for trials 1-13.

through, without preventing the oil from draining. However, such a filtration module could not be tested in this study. Because the foot is commonly recycled into the press during commercial operations, lowering the filtrate foot content would also reduce the amount of material for recycling, thus minimizing the impact on throughput.

In the first screw profile tested (profile 1), the trituration zone was composed of a succession of 10 monolobe paddles and two series of 10 bilobe paddles. The object of such a configuration was to obtain efficient mechanical lysis of the cells and therefore good release of oil. This gave the lowest press cake oil content, and the highest oil yield $\left(R_{C}\right)$ of the study (trial 1 ): $5.9 \%$ of the dry matter and $89.6 \%$, respectively (Table 1 ). However, the reduction in the size of the solid particles was so great that the quantity driven through the filter was very high $(56.1 \%$ for the mass content of the foot in the filtrate). Consequently, the oil yield $\left(R_{L}\right)$ was only $53.6 \%$ with a rather low specific mechanical energy $(33.5 \mathrm{~W} \mathrm{~h} / \mathrm{kg}$ seed processed or $196.1 \mathrm{Wh} / \mathrm{kg}$ expressed oil).

In the second screw profile tested (profile 2), the reverse screw elements were placed $25 \mathrm{~mm}$ from the end of the filtration module in an attempt to lower the foot content in the filtrate. However, the opposite was observed. In fact, this experiment (trial 2), conducted at the same screw rotation speed as the previous one ( $66 \mathrm{rpm})$, gave a higher value for the foot mass content in the filtrate: $65.1 \%$ against $56.1 \%$ (Table 1 ). In addition, the oil content in the press cake was much higher ( $19.1 \%$ of the dry matter), leading to a decrease in both oil yields $\left(R_{C}\right.$ and $\left.R_{L}\right): 59.1$ and $29.6 \%$, respectively. An increase in the foot content in the filtrate leading to higher residual oil content in the press cake, is also observed with single-screw pressing.

Increasing the screw rotation speed from 66 to $93 \mathrm{rpm}$ (trials 3 and 4) did not improve the oil extraction. Indeed, it resulted in a decrease in the mean residence time of the matter in the twinscrew extruder and in a decrease in the device's filling coefficient from 76.5 to $54.1 \mathrm{~g} / \mathrm{h} \mathrm{rpm}$ (Table 1 ), plus the compression of the mixture in the reverse screw elements was less efficient. Because the liquid/solid separation was more difficult, the oil content in the press cake increased from 19.1 to $28.0 \%$ of the dry matter, and the oil yield $\left(R_{C}\right)$ decreased from 59.1 to $30.6 \%$. In addition, the centrifugation applied to the filtrates from trials 3 and 4 did not manage to separate any expressed oil from the foot, and thus the oil yield $\left(R_{L}\right)$ was $0 \%$ for both. When the screw rotation speed was at least $79 \mathrm{rpm}$, the mechanical action in the trituration zone was probably too intense and the solid particles so small, that they were driven through the filter very easily. The use of a filter section with smaller perforations could reduce this phenomenon. But, as mentioned above, such a solution could not be considered for this study.

Profile 3 consisted of reducing the length of the trituration zone (10 monolobe paddles and only one series of 10 bilobe paddles), with the same pressing zone as for profile 1 . A first attempt (trial 5) was conducted with a screw rotation speed of $76 \mathrm{rpm}$ to avoid clogging the machine, and with the same pressing temperature as for the previous trials $\left(80^{\circ} \mathrm{C}\right)$. The reduction of the mechanical action in the trituration zone led to a slight decrease in the foot mass content in the filtrate: $51.1 \%$ instead of $56.1 \%$ for trial 1 (Table 1 ). But, such a difference had no significant effect on the oil content in the press cake, on the oil yields ( $R_{C}$ and $R_{L}$ ), or on the specific mechanical energy: $6.8 \%$ of the dry matter instead of $5.9 \%$ of the dry matter for trial $1,87.6 \%$ instead of $89.6 \%$ for trial $1,56.1 \%$ instead of $53.6 \%$ for trial 1, and $189.2 \mathrm{Wh} / \mathrm{kg}$ expressed oil instead of $196.1 \mathrm{Wh} / \mathrm{kg}$ expressed oil for trial 1, respectively.

Two other experiments were conducted with profile 3 . The screw rotation speed was very similar ( $73 \mathrm{rpm})$, but two different pressing temperatures were used: $100^{\circ} \mathrm{C}$ for trial 6 and $120^{\circ} \mathrm{C}$ for trial 7. The flow of material across the reverse pitch screws became less viscous with the increase in pressing temperature, and this led to a less efficient liquid/solid separation. Consequently, the oil content in the press cake was at least $13.3 \%$ of the dry matter (trial 7 ) instead of $6.8 \%$ of the dry matter at $80^{\circ} \mathrm{C}$, and the oil yield $\left(R_{C}\right)$ decreased from 87.6 to $71.8 \%$ and $73.8 \%$ (trials 5,6 and 7 ), respectively (Table 1). Moreover, both filtrates had a slightly higher foot content than for trial 5: 56.8 and 54.5\%, respectively. However, these two values were still too high, and the oil yield $\left(R_{L}\right)$ logically decreased from $56.1 \%$ at $80^{\circ} \mathrm{C}$ to $41.5 \%$ at $100{ }^{\circ} \mathrm{C}$ and $46.3 \%$ at $120^{\circ} \mathrm{C}$.

A fourth screw profile was also tested (profile 4). It consisted of using another type of reverse screw element in the pressing zone, with longer CF2C screws ( $50 \mathrm{~mm}$ instead of $25 \mathrm{~mm}$ ), and with a higher i.e. less restrictive pitch $(-33 \mathrm{~mm}$ instead of $-16 \mathrm{~mm})$. However, the trituration zone remained the same as for profile 3 , i.e. 10 monolobe paddles and 10 bilobe paddles. Six experiments were conducted with this profile (trials 8-13). Because the CF2C screws were longer, the device's filling coefficient needed to be lower with this profile (4) than with the three others, to avoid clogging the twin-screw extruder: no higher than $33.8 \mathrm{~g} / \mathrm{h}$ rpm instead of $54.1-77.7 \mathrm{~g} / \mathrm{h} \mathrm{rpm}$ for trials $1-7$ (Table 1 ). Trials $8-11$ evaluated the influence of screw rotation speed (from 153 to $212 \mathrm{rpm}$ ) on 
oil extraction efficiency, using a pressing temperature of $80^{\circ} \mathrm{C}$. The effect of the latter was measured in trials 8,12 and 13 where it was $80-120^{\circ} \mathrm{C}$ with a screw rotation speed of between 150 and $153 \mathrm{rpm}$. The mass content of the foot in the filtrate was never more than $42.4 \%$ for trials $8-13$, compared to at least $51.1 \%$ for all the other trials, meaning that the reverse screw elements used in profile 4 , lowered the filtrate's foot content significantly.

For trials $8-11$, the decrease in screw rotation speed from $212 \mathrm{rpm}$ (trial 11) to 153 (trial 8) directly affected the device's filling coefficient, increasing it from 23.3 to $33.8 \mathrm{~g} / \mathrm{h} \mathrm{rpm}$ (Table 1). Thus, the degree of fill of the CF2C screws increased as screw rotation speed decreased, and this led to a better pressing action on the matter and so to a more efficient liquid/solid separation. This was demonstrated by the increase in the motor's torque from $13.0 \%$ (trial 11) to $21.8 \%$ (trial 8 ) and by the corresponding decrease in the press cake oil content from 9.0 to $7.7 \%$ of the dry matter. Consequently, the oil yield $\left(R_{C}\right)$ increased slightly with decreasing screw rotation speed: from $82.2 \%$ (trial 11 ) to $85.0 \%$ (trial 8 ). Because the mass content of the foot in the filtrate decreased at the same time (from 42.4 to $32.3 \%$ ), the oil yield $\left(R_{L}\right)$ also increased, but more significantly: from $57.5 \%$ (trial 11 ) to $70.6 \%$ (trial 8 ). The same tendency has been previously observed for sunflower oil expression (Amalia Kartika et al., 2005, 2006). However, the oil extraction efficiency was not really different for the two lowest values of screw rotation speed: $70.0 \%$ for the oil yield $\left(R_{L}\right)$ at $170 \mathrm{rpm}$ (trial 9) and $70.6 \%$ at $153 \mathrm{rpm}$ (trial 8), respectively. Moreover, even if the motor's torque increased with a decrease in screw rotation speed, the specific mechanical energy per unit weight of expressed oil was largely independent of the device's filling: between 312 and $333 \mathrm{~W} \mathrm{~h} / \mathrm{kg}$.

For the optimal screw rotation speed (around $150 \mathrm{rpm}$ ), increasing the pressing temperature from 80 to $120^{\circ} \mathrm{C}$ (trials 8,12 and 13) did not improve oil extraction efficiency (Table 1 ), as already mentioned in the literature, for sunflower seeds (Amalia Kartika et al., 2005, 2006). Indeed, the influence of pressing temperature on the residence time and energy input is significantly correlated with material viscosity and degree of fill (Gautam and Choudhury, 1999a). The highest degree of fill was obtained when the flow of material across the CF2C screws was more viscous, thus the residence time and the energy input decreased with increasing pressing temperature. This led to a decrease in the motor's torque (from 21.8 to $13.9 \%$ ), to an increase in the press cake oil content (from 7.7 to $8.3 \%$ of the dry matter), to an increase in the filtrate's foot content (from 32.3 to $38.8 \%$ ), to a slight decrease in the oil yield $\left(R_{C}\right)$ (from 85.0 to $83.5 \%$ ), and above all, to a significant decrease in the oil yield $\left(R_{L}\right)$ (from 70.6 to $60.7 \%$ ).

In conclusion, the highest oil yield $\left(R_{L}\right)$ for this study was $70.6 \%$, obtained under the following operating conditions: profile 4 screw configuration, $153 \mathrm{rpm}$ screw rotation speed, $5.16 \mathrm{~kg} / \mathrm{h}$ inlet flow rate of jatropha seeds, and $80^{\circ} \mathrm{C}$ pressing temperature. In addition, the corresponding press cake quality was satisfactory (only 7.7\% residual oil content of the dry matter). Moreover, the specific mechanical energy was $71 \mathrm{Wh} / \mathrm{kg}$ seed processed or $314 \mathrm{Wh} / \mathrm{kg}$ expressed oil, which is much lower than the energy input needed with a mechanical screw press of a similar scale $(462 \mathrm{Wh} / \mathrm{kg}$ seed processed or about $1.6 \mathrm{kWh} / \mathrm{kg}$ expressed oil) (Karaj and Müller, 2011). However, these values need to be confirmed when the jatropha oil is extracted with twin-screw extruders of higher capacity. The amount of foot in the filtrate was still high under these optimal conditions (32.3\%). The corresponding throughput was $0.55 \mathrm{~kg} / \mathrm{h}$, and it represented $11 \%$ of the inlet flow rate of jatropha seeds. And once again, reducing the diameter of perforations in the filter section should diminish the filtrate foot content.

The shutdown and opening of the twin-screw extruder at the end of trial 13 made it possible to observe the location of the matter inside, along the optimized screw profile (profile 4). The monolobe paddles (DM) and especially the bilobe paddles (BB) were filled more than the conveying elements situated in modules 1-3 (Fig. 3). Their crushing ability was confirmed by the reduction in the size of the solid particles observed after each of these two restrictions (Fig. 4): $553 \mu \mathrm{m}$ and $377 \mu \mathrm{m}$ for the average particle size, respectively, compared to $1094 \mu \mathrm{m}$ at the inlet. Because of their high pressing action on the matter, leading to the liquid/solid separa-
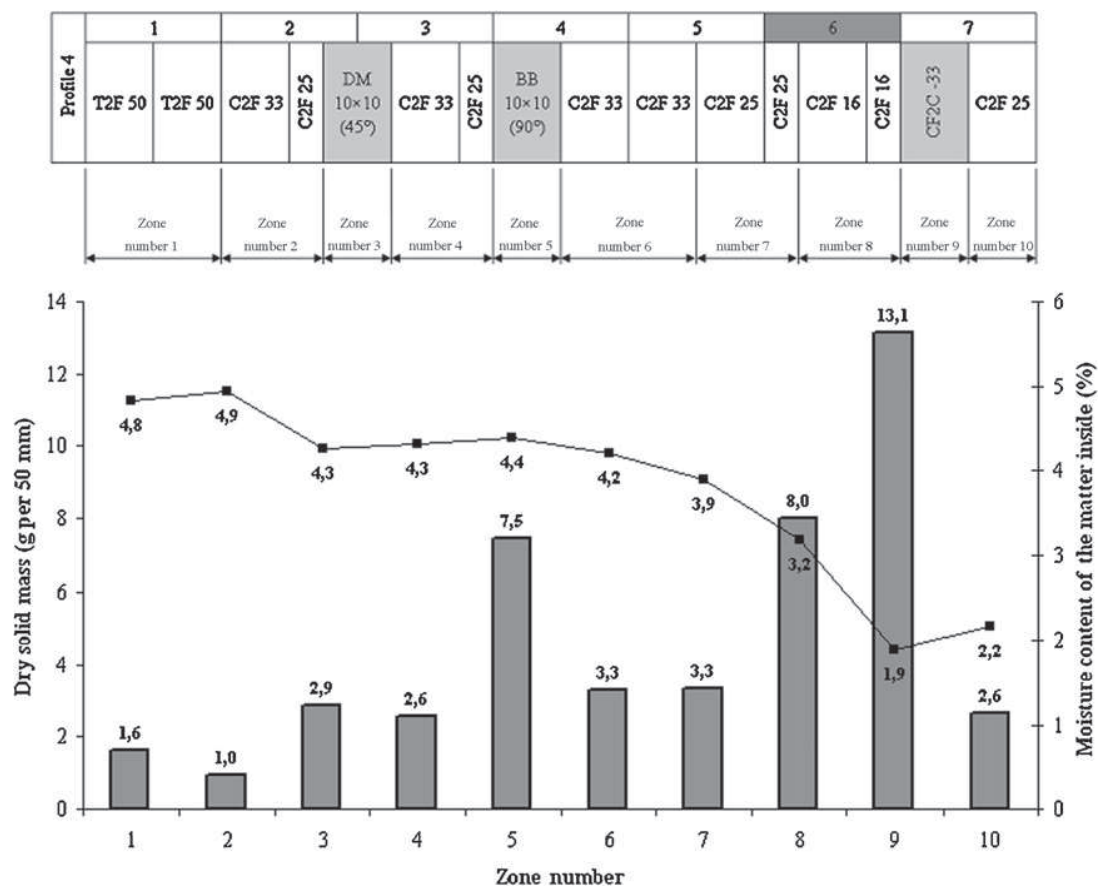

Fig. 3. Dry solid mass results for the contents of the twin-screw extruder: dry solid mass $(\square)$ and moisture content ( $\mathbf{\square})$ of the matter inside, collected in ten zones along profile 4 following shutdown and opening of the twin-screw extruder at the end of trial 13. For each zone, the dry solid mass indicated corresponds to the mass collected over a $50 \mathrm{~mm}$ zone length. T2F, trapezoidal double-thread screw; $\mathrm{C} 2 \mathrm{~F}$, conveying double-thread screw; DM, monolobe paddle-screw; BB, bilobe paddle-screw; CF2C, reverse screw. The numbers following the type of screw indicate the pitch of T2F, C2F, and CF2C screws and the length of the DM and BB screws. 


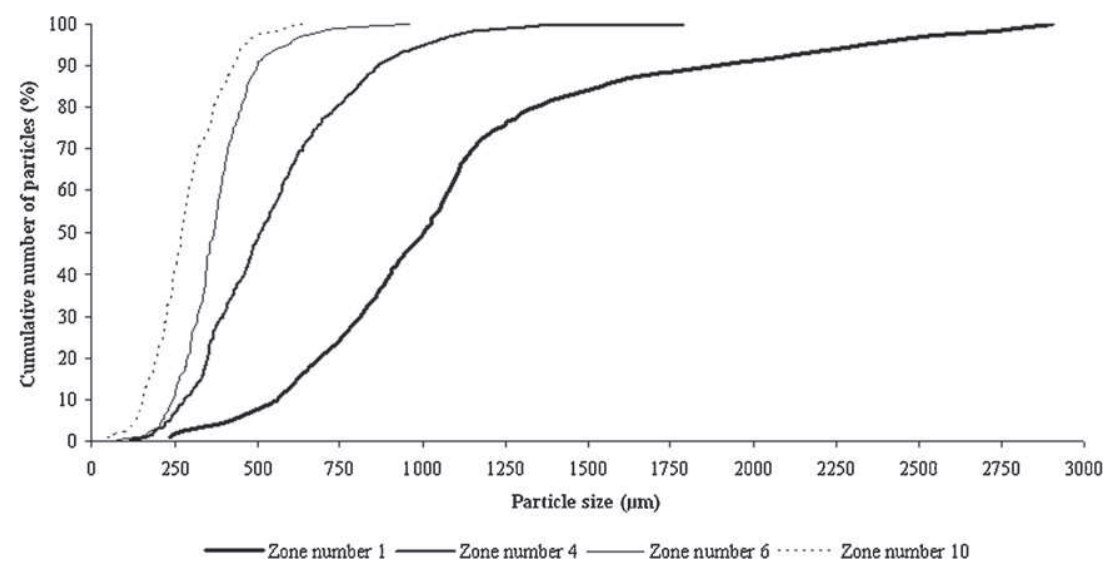

Fig. 4. Cumulative number of particles as a function of particle size for the matter inside, collected at the end of trial 13 , in zones $1,4,6$, and 10 along profile 4 .

tion, the CF2C screws (zone 9) were logically the elements of the screw profile which were most filled (Fig. 3). The intensive shearing applied to the matter also contributed to an additional reduction in the size of solid particles (Fig. 4): only $274 \mu \mathrm{m}$ for the average size in the press cake.

\subsection{Influence of operating conditions on oil quality}

The average acid values of expressed oils (Table 2) compared favorably with those obtained from the literature (Akintayo, 2004; Meher et al., 2009; Pradhan et al., 2011). The acid value was at least $5.6 \mathrm{mg}$ of $\mathrm{KOH} / \mathrm{g}$ of oil for the expressed oils from profiles $1-3$, and the two highest acid values were obtained for trials 1 and 2: $9.2 \mathrm{mg}$ of $\mathrm{KOH} / \mathrm{g}$ of oil and $6.6 \mathrm{mg}$ of $\mathrm{KOH} / \mathrm{g}$ of oil, respectively. And these two trials were associated with the highest motor's torque values: 23.8 and $37.1 \%$, respectively (Table 1 ). Consequently, greater mechanical action on the matter could perhaps contribute to an increase in the hydrolysis of the triglycerides. The lowest acid values were obtained for the expressed oils produced using the optimal screw profile (profile 4): from 5.0 to $5.4 \mathrm{mg}$ of $\mathrm{KOH} / \mathrm{g}$ of oil, or from 2.5 to $2.7 \%$ for the acidity (Table 2 ). These values are quite acceptable for subsequent synthesis of biodiesel. Indeed, the acid value has significant effects on the transesterification of triglycerides with alcohol, using a catalyst (Goodrum, 2002). In alkaline transesterification, the free fatty acids quickly react with the catalyst to produce soaps that are exceedingly difficult to separate, and this may reduce the quantity of catalyst available for transesterification, lowering the yield of biodiesel product. The soaps produced, can cause an increase in viscosity and the appearance of gels, and also make the separation of glycerol difficult (Qian et al., 2008). Low, free fatty acid content in the oil (less than $3 \%$ ), is therefore required for alkali-catalyzed transesterification (Canakci and Gerpen, 2001).

The iodine value is a measure of the level of unsaturated fats and oils. A higher iodine value indicates a higher level of unsaturated fats and oils (Kyriakidis and Katsiloulis, 2000; Knothe, 2002). For this study, the average iodine values for expressed oils were quite stable (from 73.0 to $79.6 \mathrm{~g}$ of iodine/ $100 \mathrm{~g}$ of oil) even if most of the lowest iodine values were obtained for the expressed oils produced using the optimal screw profile (profile 4): from 73.1 to $75.5 \mathrm{~g}$ of iodine/100 $\mathrm{g}$ of oil. This was confirmed by the fatty acid composition of expressed oils that was largely independent of the operating conditions used with the twin-screw extruder. As for the oil contained in the jatropha seeds, all the expressed oils were rich in oleic and linoleic fatty acids: $42.9-44.0 \%$ and $33.0-34.9 \%$, respectively. And at the same time, the contents of palmitic, palmitoleic and stearic fatty acids were: $14.1-14.9 \%, 0.7-0.8 \%$ and $6.9-7.3 \%$, respectively. However, the iodine values were lower than some reported in the literature (92.5-107.0 g of iodine/100 g of oil) (Akintayo, 2004; Meher et al., 2009; Pradhan et al., 2011), indicating that the expressed oils produced in this study were composed of glycerides with less unsaturated fatty acids.

The phosphorus content of oil extracted from jatropha seeds using the Soxhlet extraction apparatus and n-hexane as extracting solvent, was $178.1 \pm 12.7 \mathrm{mg} / \mathrm{kg}$ of oil, corresponding to $4631 \pm 330 \mathrm{mg}$ of phospholipids/kg of oil. This appeared to be higher than some literature values: $110-150 \mathrm{mg}$ of phosphorus $/ \mathrm{kg}$ of oil in the case of jatropha oils extracted under the same conditions (Naresh et al., 2012). Generally, the phosphorus content in the expressed oils was lower than in the Soxhlet extracted oil from jatropha seeds (Table 2), giving readings for trials 2-9 that were within the literature values. The expressed oil richest in phospholipids, was produced with profile 1 ( $178.3 \mathrm{mg}$ of phosphorus/ $\mathrm{kg}$ of oil or $4635 \mathrm{mg}$ of phospholipids/kg of oil), and was paired with the press cake poorest in lipids (only 5.9\% of the dry matter for its oil content) (Table 1). This indicates that here, jatropha seeds were subject to intense crushing, leading to more efficient rupturing of cell walls and so to a higher co-extraction of membrane phospholipids. Conversely, the expressed oil from profile 2 was the poorest in phospholipids (104.1 $\mathrm{mg}$ of phosphorus $/ \mathrm{kg}$ of oil or $2708 \mathrm{mg}$ of phospholipids/kg of oil), and the corresponding press cake had a high oil content (19.1\% of the dry matter). For the expressed oils from the optimal screw profile (profile 4), a high screw speed favored co-extraction of the phospholipids due to the increase in shearing action. Indeed, the phosphorus content was around $130 \mathrm{mg} / \mathrm{kg}$ of oil with a screw speed below $170 \mathrm{rpm}$ (trials 8 and 9), and it reached $170 \mathrm{mg} / \mathrm{kg}$ of oil with a screw speed of at least $191 \mathrm{rpm}$ (trials 10 and 11). Similarly, it increased from 130.1 to $174.2 \mathrm{mg} / \mathrm{kg}$ of oil when the pressing temperature was increased from 80 to $120^{\circ} \mathrm{C}$ (trials 8,12 and 13). This facilitated more effective drying of the seeds, thus more efficient crushing, due to their reduced elasticity, at the level of the CF2C screws. And this intense crushing, ruptured the cell walls and led to a more efficient co-extraction of the membrane phospholipids, as previously reported by Lacaze-Dufaure et al. (1999) and Amalia Kartika et al. $(2005,2006)$ for sunflower oil extraction in a twin-screw extruder. The same phenomenon was also observed for the expressed oils from profile 3 , where the highest phosphorus content $(144.9 \mathrm{mg} / \mathrm{kg}$ of oil) corresponded to the $120^{\circ} \mathrm{C}$ pressing temperature (trial 7). However, if necessary, phospholipids can be removed from the expressed oils using a degumming process. A recent study showed that the phosphorus content of an oil extracted from jatropha seeds by mechanical pressing, decreased from 46 to approximately $2.3 \mathrm{mg} / \mathrm{kg}$ of oil after combining water degumming and 


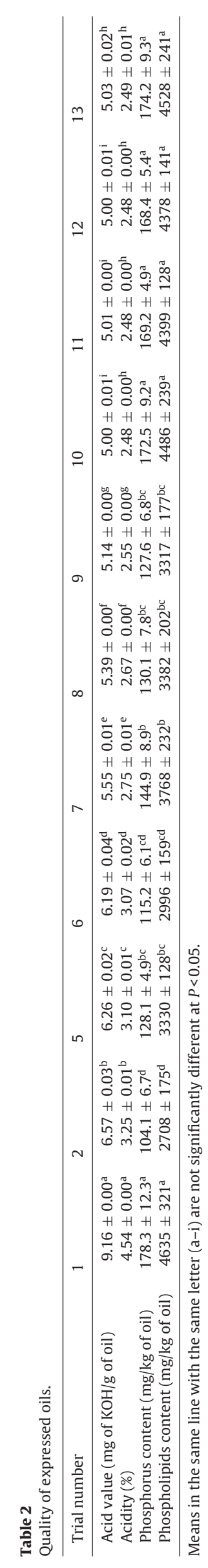

acid degumming steps, and it was less than $1 \mathrm{mg} / \mathrm{kg}$ of oil after membrane filtration (Liu et al., 2012).

The density of the expressed oils was between 915.0 and $917.8 \mathrm{~kg} / \mathrm{m}^{3}$, meaning that it was relatively independent of the twin-screw extrusion conditions, as previously observed for the iodine value. At the same time, the dynamic viscosity was between 30.2 and $34.5 \mathrm{mPa}$ s and the kinematic viscosity between 32.9 and $37.7 \times 10^{-6} \mathrm{~m}^{2} / \mathrm{s}$, which are close to the acceptable values quoted in the literature for jatropha oil (Akintayo, 2004; Meher et al., 2009; Pradhan et al., 2011).

\subsection{Potential uses of the press cakes}

In this study, the oil content in the press cake was at least $5.9 \%$ of the dry matter (Table 1 ). Although this could be a disadvantage for direct utilization of the cake, it could be converted into usable energy by combustion, gasification or pyrolysis (Yorgun et al., 2001; Gerçel, 2002). As a mixture of proteins and lignocellulosic fibers coming mainly from the shells but also from the kernel breakdown process, the press cake can also be considered as a natural composite. Thus, it could be transformed into biodegradable and value-added agromaterials by thermo-pressing (Evon et al., 2010a,b, 2012), by injection molding (Rouilly et al., 2006) or by using a casting technique (Gueguen et al., 1998). Finally, the press cake could act as reinforcing filler for a biodegradable polymer, i.e. polycaprolactone (PCL), and have potential uses in biocomposite applications (Diebel et al., 2012).

\section{Conclusion}

The extraction of oil from jatropha seeds by mechanical pressing was carried out using the twin-screw extrusion technology. The operating conditions (screw configuration, screw rotation speed and pressing temperature) had an important influence on the oil yield, the specific mechanical energy and the quality of the expressed oil. The lowest foot contents for the filtrate (31-42\%), were obtained with 10 monolobe paddles and 10 bilobe paddles in the trituration zone, and with $-33 \mathrm{~mm}$ reverse pitch screws, $50 \mathrm{~mm}$ in length, in the pressing zone. The oil yield was at least $57 \%$ with such a screw profile, and it systematically increased as the screw rotation speed and pressing temperature were decreased. The highest oil yield of $71 \%$ was obtained under operating conditions of $153 \mathrm{rpm}$ and $80^{\circ} \mathrm{C}(5.16 \mathrm{~kg} / \mathrm{h}$ for the inlet flow rate of jatropha seeds). But, the mass content of the foot in the filtrate was high (32\%) under these conditions. The quality of the corresponding press cake was reasonable, with a residual oil content of less than $8 \%$ of the dry matter. Moreover, the extrusion process using the optimal operating conditions, produced an oil of good quality for biodiesel production, and at a moderate cost.

\section{References}

Achten, W.MJ Verchot, L, Franken, YJ Mathijs, E, Singh, V.P., Aerts, R, Muys, B. 2008. Jatropha bio-diesel production and use. Biomass Bioenergy 32, 1063-1084. Akintayo, E.T., 2004. Characteristics and composition of Parkia biglobbossa and Jatropha curcas oils and cakes. Bioresour. Technol. 92, 307-310.

Amalia Kartika, I., Pontalier, P.Y., Rigal, L., 2005. Oil extraction of oleic sunflower seeds by twin screw extruder: influence of screw configuration and operating conditions. Ind. Crops Prod. 22, 207-222.

Amalia Kartika, I., Pontalier, P.Y., Rigal, L., 2006. Extraction of sunflower oil by twin screw extruder: screw configuration and operating condition effects. Bioresour. Technol. 97, 2302-2310.

AOAC, 2006. Official Methods of Analysis of AOAC International, 18th ed. Association of Official Analytical Chemists, Washington, DC

Becker, K., Makkar, H.P.S., 2008. Jatropha curcas: a biodiesel source for tomorrow's oil and biodiesel. Lipid Technol. 20, 104-107.

Bouvier, J.M., Guyomard, P., 1997. Method and installation for continuous extraction of a liquid contained in a raw material. PCT/FR97/00696.

Canakci, M., Gerpen, J.V., 2001. Biodiesel from oils and fats with high free fatty acids. Trans. Am. Soc. Agric. Eng. 44, 1429-1436. 
Choudhury, G.S., Gogoi, B.K., Oswalt, A.J., 1998. Twin screw extrusion of pink salmon muscle and rice flour blends: effects of kneading elements. J. Aquat. Food Prod. Technol. 7, 69-91.

Crowe, T.W., Johnson, L.A., Wang, T., 2001. Characterization of extruded-expelled soybean flours. J. Am. Oil Chem. Soc. 78, 775-779.

Diebel, W., Reddy, M.M., Misra, M., Mohanty, A., 2012. Material property characterization of co-products from biofuel industries: potential uses in value-added biocomposites. Biomass Bioenergy 37, 88-96.

Dziezak, J.D., 1989. Single and twin-screw extruders in food processing. Food Technol., 164-174.

Evon, Ph., Vandenbossche, V., Pontalier, P.Y., Rigal, L., 2007. Direct extraction of oi from sunflower seeds by twin-screw extruder according to an aqueous extraction process: feasibility study and influence of operating conditions. Ind. Crops Prod. 26, 351-359.

Evon, Ph., Vandenbossche, V., Pontalier, P.Y., Rigal, L., 2009. Aqueous extraction of residual oil from sunflower press cake using a twin-screw extruder: feasibility study. Ind. Crops Prod. 29, 455-465.

Evon, Ph., Vandenbossche, V., Pontalier, P.Y., Rigal, L., 2010a. Thermo-mechanica behaviour of the raffinate resulting from the aqueous extraction of sunflowe whole plant in twin-screw extruder: manufacturing of biodegradable agromaterials by thermo-pressing. Adv. Mater. Res. 112, 63-72.

Evon, Ph., Vandenbossche, V., Pontalier, P.Y., Rigal, L., 2010b. The twin-screw extrusion technology, an original and powerful solution for the biorefinery of sunflower whole plant. Ol. Corps Gras Li. 17, 404-417.

Evon, Ph., Vandenbossche, V., Rigal, L., 2012. Manufacturing of renewable and biodegradable fiberboards from cake generated during biorefinery of sunflower whole plant in twin-screw extruder: influence of thermo-pressing conditions. Polym. Degrad. Stab. 97, 1940-1947.

Faye, M., 2010. Nouveau procédé de fractionnement de la graine de Neem (Azadirachta indica A. Jussi) sénégalais: production d'un bio-pesticide, d'huile et de tourteau. PhD Thesis. INP, Toulouse, France.

Foidl, N., Foidl, G.G., Sanchez, M., Mittelbach, M., Hackel, S., 1996. Jatropha curcas L. as a source for the production of biofuel in Nicaragua. Bioresour. Technol. 58, 77-82.

Gautam, A., Choudhury, G.S., 1999a. Screw configuration effect on residence time distribution and mixing in twin-screw extruder during extrusion of rice flour. J. Food Process Eng. 22, 263-285.

Gautam, A., Choudhury, G.S., 1999b. Screw configuration effect on starch breakdown during twin screw extrusion of rice flour. J. Food Process. Preserv. 23, 355-375.

Gerçel, H.F., 2002. The production and evaluation of bio-oils from the pyrolysis of sunflower-oil cake. Biomass Bioenergy 23, 307-314.

Gogoi, B.K., Choudhury, G.S., Oswalt, A.J., 1996. Effects of location and spacing of reversed screw and kneading element combination during twin-screw extrusion of starchy and proteinaceous blends. Food Res. Int. 29, 505-512.

Goodrum, J.W., 2002. Volatility and boiling points of biodiesel from vegetable oils and tallow. Biomass Bioenergy 22, 205-211.

Gubiz, G.M., Mittelbach, M., Trabi, M., 1999. Exploitation of the tropical oil seed plant Jatropha curcas L. Bioresour. Technol. 67, 73-82.

Gueguen, J., Viroben, G., Noireaux, P., Subirade, M., 1998. Influence of plasticizer and treatment on the properties of film from pea proteins. Ind. Crops Prod. 7 , 149-157.

Guyomard, P., 1994. Study of the use of a twin-screw extruder in pressing-extrusion of oleagineous seeds. PhD Thesis. Université Technologique de Compiègne, France.
Haas, W., Mittelbach, M., 2000. Detoxification experiments with the seed oil from Jatropha curcas L. Ind. Crops Prod. 12, 111-118.

Isobe, S., Zuber, F., Uemura, K., Noguchi, A., 1992. A new twin-screw press design for oil extraction of dehulled sunflower seeds. J. Am. Oil Chem. Soc. 69, 884-889.

Karaj, S., Müller, J., 2011. Optimizing mechanical oil extraction of Jatropha curcas L. seeds with respect to press capacity, oil recovery and energy efficiency. Ind. Crops Prod. 34, 1010-1016.

Knothe, G., 2002. Structure indices in FA chemistry. How relevant is the iodine value? J. Am. Oil Chem. Soc. 9, 847-853.

Kumar, A., Sharma, S., 2008. An evaluation of multipurpose oil seed crop for industrial uses (Jatropha curcas L.): a review. Ind. Crops Prod. 28, 1-10.

Kyriakidis, N.B., Katsiloulis, T., 2000. Calculation of iodine value from measurements of fatty acid methyl esters of some oils: comparison with the relevant American Oil Chemists' Society method. J. Am. Oil Chem. Soc. 77, 1235-1238.

Lacaze-Dufaure, C., Leyris, J., Rigal, L., Mouloungui, Z., 1999. A twin-screw extruder for oil extraction: I. Direct expression of oleic sunflower seeds. J. Am. Oil Chem. Soc. 76, 1073-1079.

Liu, K.T., Gao, S., Chung, T.W., Huang, C.M., Lin, Y.S., 2012. Effect of process conditions on the removal of phospholipids from Jatropha curcas oil during the degumming process. Chem. Eng. Res. Des. 90, 1381-1386.

Meher, L.C., Naik, S.N., Naik, M.K., Dalai, A.K., 2009. Biodiesel production using Karanja (Pongamia pinnata) and Jatropha (Jatropha curcas) seed oil. In: Pandey, A. (Ed.), Handbook of Plant-based Biofuels. CRC Press, New York, p. 257.

Naresh, B., Srikanth Reddy, M., Vijayalakshmi, P., Reddy, V., Devi, P., 2012. Physicochemical screening of accessions of Jatropha curcas for biodiesel production. Biomass Bioenergy 40, 155-161.

Ofori-Boateng, C., Teong, L.K., JitKang, L., 2012. Comparative exergy analyses of Jatropha curcas oil extraction methods: solvent and mechanical extraction processes. Energy Convers. Manage. 55, 164-171.

Openshaw, K., 2000. A review of Jatropha curcas: an oil plant of unfulfilled promise. Biomass Bioenergy 19, 1-15.

Pradhan, R.C., Mishra, S., Naik, S.N., Bhatnagar, N., Vijay, V.K., 2011. Oil expression from Jatropha seeds using a screw press expeller. Biosyst. Eng. 109, 158-166.

Qian, J., Wang, F., Liu, S., Yun, Z., 2008. In situ alkaline transesterification of cottonseed oil for production of biodiesel and nontoxic cottonseed meal. Bioresour. Technol. 99, 9009-9012.

Rigal, L., 1996. Twin-screw Extrusion Technology and Fractionation of Vegetable Matter. ENSC, Toulouse, France.

Rouilly, A., Orliac, O., Silvestre, F., Rigal, L., 2006. New natural injection-moldable composite material from sunflower oil cake. Bioresour. Technol. 97, 553-561.

Singh, K.K., Wiesenborn, D.P., Tostenson, K., Kangas, N., 2002. Influence of moisture content and cooking on screw pressing of crambe seed. J. Am. Oil Chem. Soc. 79, $165-170$.

Sriti, J., Msaada, K., Talou, T., Faye, M., Amalia Kartika, I., Marzouk, B., 2012. Extraction of coriander oil by twin-screw extruder: screw configuration and operating conditions effect. Ind. Crops Prod. 40, 355-360.

Tambunan, A.H., Situmorang. J.P., Silip, J.J., Joelianingsih, A., Araki, T., 2012. Yield and physicochemical properties of mechanically extracted crude Jatropha curcas L. oil. Biomass Bioenergy 43, 12-17.

Wang, T., Johnson, L.A., 2001. Refining normal and genetically enhanced soybean oils obtained by various extraction methods. J. Am. Oil Chem. Soc. 78, 809-815.

Yorgun, S., Sensöz, S., Kockar, Ö.M., 2001. Flash pyrolysis of sunflower oil cake for production of liquid fuels. J. Anal. Appl. Pyrolysis 60, 1-12.

Zheng, Y., Wiesenborn, D.P., Tostenson, K., Kangas, N., 2003. Screw pressing of whole and dehulled flaxseed for organic oil. J. Am. Oil Chem. Soc. 80, 1039-1045. 